\title{
The Monetary Transmission Mechanism in Brazil: Evidence from a VAR Analysis
}

\author{
- VIVIANE LUPORINI*
}

\begin{abstract}
RESUMO
Esse artigo analisa o canal juros do mecanismo de transmissão monetária sobre o produto, preços e taxa de câmbio na economia brasileira dos anos 90 através dos efeitos de uma redução inesperada na taxa básica de juros em um sistema de vetores auto-regressivos. Os principais resultados obtidos são: a) um choque monetário afeta imediatamente a atividade econômica, reduzindo a taxa de crescimento do PIB; b) a inflação e a taxa de câmbio são afetadas somente após um intervalo de tempo, e a inflação assume uma tendência declinante somente dois meses após o choque de juros; c) os resultados são robustos quando controlados para condições internacionais, preço das commodities ou outras medidas de inflação e atividade econômica; d) choques monetários afetam significativamente a volatilidade do produto e da inflação no modelo padrão; e) choques monetários afetam significativamente a volatilidade da relação dívida/PIB no modelo de controle.
\end{abstract}

\section{Palavras-CHave}

política monetária, mecanismo de transmissão monetária, Brasil

\begin{abstract}
This article presents evidence on the interest channel of the monetary policy for the Brazilian economy of the 1990s analyzing the effects of an unexpected change in the baseline interest rate on output, prices and the exchange rate in a vector autoregression system. Our main results are: a) a tightening in the monetary policy affects economic activity immediately, reducing the rate of growth of real GDP; $b$ ) the exchange rate and prices are affected only after a time interval, with inflation assuming a downward trend only two months after the monetary shock; c) results do not change when the specification is controlled for international conditions, commodity prices or other measures of inflation and economic activity; d) monetary shocks have a significant impact on the volatility of output and inflation in the benchmark model e) monetary shocks have a significant impact on the volatility of the debt/GDP ratio in the control-model.
\end{abstract}

KEYWORDS

monetary policy, monetary transmission mechanism, Brazil

JEL ClassificATION

E52

* Professora do Instituto de Economia da Universidade Federal do Rio de Janeiro (UFRJ) e pesquisadora do CNPq. Endereço para contato: Instituto de Economia - IE, UFRJ - Praia Vermelha - Avenida Pasteur, 250, sala 103, Urca - Rio de Janeiro - RJ. CEP: 22290-240. E-mail: viviane.luporini@ie.ufrj.br.

(Recebido em outubro de 2003. Aceito para publicação em maio de 2007). 


\section{INTRODUCTION}

This paper presents evidence on the interest channel of the monetary policy for the Brazilian economy of the 1990s. Most economists tend to agree that actions by the monetary authority have real effects on the economy, altering the time path of real output and employment at least in the short run. On the empirical level, several studies have indeed shown that contractionary monetary policy actions, usually characterized by increases in the baseline nominal interest rate, tend to be followed by reductions in economic activity while expansionary actions are usually accompanied by increments in production and employment [see for example, Friedman and Schwartz (1963); Romer and Romer (1989); Cook and Hahn (1989); Sims (1992); Cochrane (1998); Barth and Ramey (2000)]. The reasons for this "empirical regularity" have been the subject of substantial controversy and produced a large literature on why and how changes in monetary policy may affect real variables (Blanchard,1990). Although the dispute may in fact reflect different views on how the real world actually works, the main explanations for the non-neutrality of monetary policy have been centered on informational issues, problems of signal extraction and expectation formation on one side, contracts, rigidities (nominal and real) and coordination problems on another. Theoretical disagreements standing, the important question from the policymaker's point of view is not so much why monetary policy is not neutral, but how the main aggregates in the economy respond to actual changes in the monetary instruments available.

The applied literature on the monetary transmission mechanism mostly analyses the American case and European countries, identifying the actions of the monetary authority as a shock to either some monetary aggregate [Barro (1977), Reichenstein (1987), Cochrane (1994)] or to the baseline interest rate [Bernanke and Gertler (1995), Bernanke and Blinder (1992), Christiano, Eichenbaum and Evans (1994, 1999), Peerman and Smets (2001)]. For the Brazilian case, Mendonça (2001) discusses the monetary and lending channels of monetary policy and provides an application of the Taylor's rule to the determination of the interest rate after 1999. Barbosa and Portugal (2002) use autoregressive distributed-lag models to estimate the effect of changes in the long-run real interest rate on the output gap. The authors are interested in estimating the parameters of the IS and Phillips curves in order to investigate inflation target models. Minella (2001) analysis the monetary transmission mechanism for Brazil. The author uses a vector autoregressive system of first integrated variables to investigate the dynamics of inflation during periods of moderately increasing inflation, high and low inflation. Regarding the monetary transmission mechanism, the author finds that for all three periods, monetary policy shocks have real effects on output but do not induce an immediate reduction in inflation rates. 
This paper follows the international empirical literature in terms of the methodology and examines the response patterns of main economic variables to an unanticipated tightening in the Brazilian monetary policy through a vector autoregression system of equations (VAR). Our analysis differs from Minella's in three important ways. First, our benchmark specification includes the exchange rate as one of the endogenous variables in the model. Since the early 1990s, as the Brazilian economy began to open to international trade, this variable has become an important component of internal prices as well as monetary policy decision-making. Second, given the well-known sensitivity of impulse response functions to different specifications, the paper presents a sequence of alternative specification schemes providing a robustness analysis for the results. Finally, the paper sheds some light on how unexpected monetary policy shocks have contributed to the volatility of the economic aggregates in the model. The benchmark model finds that a tightening in the rate of change of the nominal selic rate has an immediate effect on economic activity, reducing the rate of growth of real GDP and a delayed effect on the rate of inflation, the main declared goal of the policymaker.

The paper is organized as follows. The second section presents the theoretical model of the VAR system, the third presents the evidence on the interest channel of the monetary policy, the fourth section brings the robustness analysis for the results obtained by the benchmark model and discusses the so-called "price-puzzle". The fifth section describes the effects of the monetary shock on the volatility of the economic aggregates of the model and the sixth section concludes the article.

\section{THE MODEL}

A monetary shock is identified as the disturbance term in the general equation:

$$
S_{t}=f\left(I_{t}\right)+\sigma \varepsilon_{t}
$$

where $S$ represents the monetary authority's policy instrument, the baseline interest rate or some monetary aggregate, $I$ represents the information set available to the policymaker at time $t, \sigma \varepsilon$ is a random variable representing a monetary shock and $f$ is a function, assumed linear, relating the policy instrument $S$ to the information $I_{t}$.

The monetary shock may reflect exogenous changes in the monetary authority loss function due to relative shifts in the preference for inflation and unemployment, for example, or shifts in the political composition of the government (Christiano et al.,1999), strategic actions by the monetary authority to avoid social costs associated 
with unfulfilled expectations formed by private economic agents [Ball (1995), Chari, Christiano and Eichenbaum (1998)], exogenous variations in the monetary policy due to technical factors such as corrections in the preliminary data used by the Central Bank when making policy decisions (Bernanke and Mihov, 1995).

A widely used strategy for estimating the effects of monetary policy shock is to adopt the recursiveness assumption that the monetary shocks are orthogonal to the information set $I$ used by the policymaker and then estimate the dynamic responses of the variable of interest to a monetary policy shock. This assumption is convenient because it justifies estimating the dynamic responses as a two-step procedure: first, the monetary policy shocks are obtained by the fitted residuals of the ordinary least squares regression of $S$ on variables in the information set $I$; then, the dynamic response is estimated by regressing the variable of interest against current and lagged values of the policy shocks estimated in the first step. This two-step procedure is, moreover, summarized by an asymptotically equivalent system of vector autoregressions (VAR) [Christiano et al. (1999)].

Consider a VAR for the vector of variables $Z_{t}$ :

$$
Z_{t}=B_{1} Z_{t-1}+\ldots .+B_{q} Z_{t-q}+u_{t} \text {, and } E u_{t} u_{t}^{\prime}=V
$$

where $u_{t}$ is uncorrelated with variables observed in period $t-1$ and earlier.

Ordinarily least squares of each equation in (2) produce consistent estimates of the coefficients and the $V$ can be estimated from the fitted residuals.

Assume that the vector of disturbances in the VAR is related to the economic shocks $\varepsilon_{t}$ according to $A_{0} u_{t}=\varepsilon_{t}$, where $A_{0}$ is an invertible square matrix. $E \varepsilon_{t} \varepsilon_{t}^{\prime}=D$, with $D$ a positive definite matrix. Then, premultiplying (2) by $A_{0}$, gives:

$$
A_{0} Z_{t}=A_{1} Z_{t-1}+\ldots .+A_{q} Z_{t-q}+\varepsilon_{t}
$$

where $A_{i}, i=0,1, \ldots, q$ is a matrix of constants; $B_{i}=A_{0}^{-1} A_{i}, i=1, \ldots, q$, and $V=A_{0}^{-1} D\left(A_{0}^{-1}\right)$.

The responses of $Z_{t+h}$ to a unit shock in the elements of $\varepsilon_{t}$ is given by:

$$
\gamma_{h}=\bar{\gamma}_{h} A_{0}^{-1}, \quad h=0,1, \ldots
$$


where $\bar{\gamma}_{h}$ is the solution to the difference equation $\bar{\gamma}_{h}=B_{1} \bar{\gamma}_{h-1}+B_{2} \bar{\gamma}_{h-2}+\ldots+B_{q} \bar{\gamma}_{h-q}$, $h=1,2, \ldots$, with initial conditions $\bar{\gamma}_{0}=I$, the identity matrix, $\bar{\gamma}_{-1}=\bar{\gamma}_{-2}=\ldots=\bar{\gamma}_{-q}=0$.

The recursive assumption that the monetary shocks are orthogonal to the information set $I$ used by the policymaker restricts $A_{0}$.

Although the recursiveness assumption is not sufficient to identify all the elements of $A_{0}$, it is sufficient to identify the dynamic response of $Z_{t}$ to a monetary shock. By selecting a lower triangular matrix with nonnegative terms on the diagonal such that $A_{0}^{-1}\left(A_{0}^{-1}\right)=V$, the dynamic responses of the variables in $Z_{t}$ will be invariant to the ordering of variables prior to the last variable in the information set (or the last variable ordered in the VAR). It is worth noting that in the absence of further restrictions, the dynamic responses to shocks to the other variables in the system simply reflect the normalization of $A_{0}$ adopted.

\section{RESPONSES TO POLICY SHOCKS: THE EVIDENCE}

There are basically two branches in the applied literature on the monetary transmission mechanism. The first one usually identifies the monetary policy shocks as innovations to some monetary aggregate, the monetary base, the money stock or M2 [Barro (1977), Reichenstein (1987), Cochrane (1994)]. The second trend, interprets policy shocks as innovations to the baseline interest rate [Bernanke and Gertler (1995), Bernanke and Blinder (1992), Christiano, Eichenbaum and Evans (1994, 1999)]. As most of the applied literature analyses the American case, the authors employ the federal funds rate as an indicator for the monetary policy. Peersman and Smets (2001) use the three-month interest rate as the monetary policy instrument for an analysis of the Euro area.

The Brazilian monetary authorities have been using the open-market interest rate as its main policy instrument. For this reason, the policy instrument considered in the analysis is the short-run interest rate (Selic).

In order to observe the fine timing of the transmission of interest rate shocks to the economy, the data set used consists of monthly observations, from January 1990 through August 2001. The raw data set used in the benchmark model consists of monthly observations of GDP, seasonally adjusted at constant average prices of 1990; the inflation rate, measured as the percentage change in the General Price Index; the 
Real/US dollar exchange rate; the overnight market interest rate (Selic). These variables are denoted by output, inflation, erate and interest, and were log-transformed to facilitate interpretation. Exception is made to the interest rate, which is measured in percentage points. The inflation rate was negative for September of 1995 (-1.08 percent). In order to apply the $\log$ operator, a constant $c=1.1$ was added to the inflation rate over the whole period. This procedure is usual and does not affect the coefficients of interest as the added constant simply alters the intercept of the inflation regression equation. Data for the robustness analysis include an index for world exports, the U.S. Prime rate, a consumer price index (IPCA), an index for industrial production; the internal debt/GDP ratio, a commodity price index and the price for crude oil. The details for the series used are presented in the appendix.

\subsection{Unit Root Tests}

Before estimating the vector autoregression system, the variables must be tested for the order of integration. As suggested by Hayashi (2000), the unit root tests were performed on a constant only, unless there is strong evidence of a deterministic time trend. This was the case for the output variable. The results are presented in Table 1.

The Augmented Dickey-Fuller (ADF) and Phillips-Perron (PP) tests have indicated that Inflation, Erate, Commodity, Oil, Debt, US Prime, World Exports, and the IPCA Index have unit roots at the 5\% significance level; Output, Interest and the Production Index do not have unit roots and may be considered stationary processes. Both the ADF and PP tests are known to have poor finite-sample properties (Hayashi, 2000, p. 601). The Dickey-Fuller-Generalized Least Squares test (DF-GLS), which has better finite-sample properties and good power, confirm the unit root results for Inflation, Erate, Commodity, Oil, Debt, US Prime, World Exports and IPCA Index, and indicate the presence of a unit root for Interest at 5\% and Output at 1\%. The Production Index remains stationary in level. In accordance to the unit root tests results, all variables in the system will be treated as integrated of first order, $\mathrm{I}(\mathrm{l}) .^{1}$

1 The Production Index variable is used in the robustness analysis presented below, both as $\mathrm{I}(0)$ and as I(1) with similar results. 
TABLE 1 - UNIT ROOT TESTS: ADF, PP AND DF-GLS

\begin{tabular}{|c|c|c|c|c|c|c|c|}
\hline \multirow{3}{*}{$\begin{array}{l}\text { Unit Root Tests } \\
\text { Variables }\end{array}$} & \multicolumn{4}{|c|}{ Augmented Dickey-Fuller and Phillips-Perron } & & & \\
\hline & \multirow[t]{2}{*}{ Sample } & \multirow[t]{2}{*}{ Det. Terms } & \multicolumn{2}{|c|}{ Test Stat } & \multicolumn{3}{|c|}{ Critical Values } \\
\hline & & & ADF & $\mathrm{PP}$ & $1 \%$ & $5 \%$ & $10 \%$ \\
\hline Output & 1990:03-2001:08 & c, trend & -4.457 & -4.996 & -4.026 & -3.443 & -3.146 \\
\hline Inflation & 1990:03-2001:08 & & -2.352 & -2.788 & -3.479 & -2.883 & -2.578 \\
\hline Erate & 1990:03-2001:08 & & -1.209 & -1.081 & -3.479 & -2.883 & -2.578 \\
\hline Interest & 1990:03-2001:08 & C & -3.878 & -3.936 & -3.478 & -2.882 & -2.578 \\
\hline Commodity & 1990:02 2001:08 & C & -0.353 & -0.754 & -3.478 & -2.882 & -2.578 \\
\hline Debt & $1991: 03$ 2001:08 & C & -0.551 & -0.194 & -3.481 & -2.884 & -2.579 \\
\hline US Prime & 1990:05 2001:08 & C & -2.602 & -2.033 & -3.479 & -2.883 & -2.578 \\
\hline World Exports & 1990:03 2001:08 & C & -1.594 & -1.375 & -3.479 & -2.883 & -2.578 \\
\hline Production Index & $1990: 02$ 2001:08 & C & -3.023 & -2.758 & -3.479 & -2.883 & -2.578 \\
\hline IPCA Index & 1990:02 2001:08 & C & -2.054 & -2.031 & -3.478 & -2.882 & -2.578 \\
\hline D(Output) & 1990:04-2001:08 & $c$, trend & -10.346 & -17.819 & -4.026 & -3.443 & -3.146 \\
\hline $\mathrm{D}$ (Inflation) & 1990:04-2001:09 & C & -11.631 & -18.885 & -3.478 & -2.882 & -2.578 \\
\hline $\mathrm{D}$ (Erate) & 1990:04-2001:10 & C & -8.482 & -8.052 & -3.479 & -2.882 & -2.578 \\
\hline $\mathrm{D}$ (Interest) & 1990:04-2001:11 & C & -10.244 & -27.021 & -3.478 & -2.882 & -2.578 \\
\hline D(Commodity) & $1990: 03$ 2001:08 & C & -10.391 & -10.682 & -3.478 & -2.882 & -2.578 \\
\hline $\mathrm{D}($ Debt $)$ & 1991:03 2001:08 & C & -7.363 & -7.363 & -3.478 & -2.884 & -2.579 \\
\hline $\mathrm{D}$ (Prime) & 1990:04 2001:08 & C & -4.722 & -6.879 & -3.479 & -2.883 & -2.578 \\
\hline D(World Exports) & $1990: 03$ 2001:08 & C & -8.844 & -8.967 & -3.479 & -2.883 & -2.578 \\
\hline $\mathrm{D}$ (Production) & $1990: 04$ 2001:08 & C & -10.543 & -20.918 & -3.479 & -2.883 & -2.578 \\
\hline D(IPCA Index) & 1990:04 2001:08 & C & -9.573 & -9.932 & -3.479 & -2.883 & -2.578 \\
\hline \multirow{3}{*}{$\begin{array}{l}\text { Unit Root Tests } \\
\text { Variables }\end{array}$} & \multicolumn{7}{|c|}{ Dickey-Fuller GLS } \\
\hline & \multirow[t]{2}{*}{ Sample } & Det. Terms & \multicolumn{2}{|c|}{ Test Stat } & \multicolumn{3}{|c|}{ Critical Values } \\
\hline & & & GLS & & $1 \%$ & $5 \%$ & $10 \%$ \\
\hline Output & 1990:04-2001:08 & c, trend & -3.029 & & -3.534 & -2.992 & -2.702 \\
\hline Inflation & 1990:04-2001:08 & C & -0.745 & & -2.582 & -1.943 & -1.615 \\
\hline Erate & 1990:04-2001:08 & C & -1.153 & & -2.582 & -1.943 & -1.615 \\
\hline Interest & 1990:04-2001:08 & C & -0.568 & & -2.582 & -1.943 & -1.615 \\
\hline Commodity & $1990: 02$ 2001:08 & C & -0.439 & & -2.582 & -1.943 & -1.615 \\
\hline Debt & 1991:03 2001:08 & C & 0.508 & & -2.583 & -1.943 & -1.615 \\
\hline US Prime & 1990:05 2001:08 & C & -1.133 & & -2.582 & -1.943 & -1.615 \\
\hline World Exports & 1990:03 2001:08 & C & -1.542 & & -2.582 & -1.943 & -1.615 \\
\hline Production Index & 1990:05 2001:08 & C & -3.252 & & -2.582 & -1.943 & -1.615 \\
\hline IPCA Index & 1990:02 2001:08 & C & -0.366 & & -2.582 & -1.943 & -1.615 \\
\hline $\mathrm{D}$ (Output) & 1990:06-2001:08 & $c$, trend & -13.817 & & -3.534 & -2.992 & -2.702 \\
\hline $\mathrm{D}$ (Inflation) & 1990:06-2001:08 & C & -11.671 & & -2.582 & -1.943 & -1.615 \\
\hline $\mathrm{D}$ (Erate) & 1990:06-2001:08 & C & -6.912 & & -2.582 & -1.943 & -1.615 \\
\hline $\mathrm{D}$ (Interest) & $1990: 06-2001: 08$ & C & -3.303 & & -2.582 & -1.943 & -1.615 \\
\hline $\mathrm{D}$ (Commodity) & 1990:04-2001:08 & C & -6.235 & & -2.582 & -1.943 & -1.615 \\
\hline $\mathrm{D}($ Debt $)$ & 1991:05 2001:08 & C & -2.417 & & -2.584 & -1.943 & -1.615 \\
\hline D(US Prime) & 1990:05 2001:08 & C & -3.332 & & -2.582 & -1.943 & -1.615 \\
\hline D(World Exports) & $1990: 05$ 2001:08 & C & -2.405 & & -2.582 & -1.943 & -1.615 \\
\hline D(IPCA Index) & 1990:04 2001:08 & C & -9.593 & & -2.582 & -1.943 & -1.615 \\
\hline
\end{tabular}




\subsection{The VAR Estimation}

The benchmark specification of the vector autoregression system was estimated using the following variables: output, inflation, erate, and interest, in this order, all in first difference.

Inflation and real GDP captures general movements in the price level and economic activity. Movements in the real exchange rate is usually taken into account by the Brazilian central bank when making monetary policy decisions. For this reason, the exchange rate is included in the VAR to identify the part of interest rate movements that might be endogenous to the exchange rate.

According to the specification used, the monetary authority is assumed to have information on the current level of economic activity, the inflation rate and the Real/US dollar exchange rate when setting its policy variable. One may argue that the policymaker usually does not have data on the current GDP level at its disposal when setting the interest rate. Although this is certainly true, the policymaker does have access to a series of partial indicators of economic activity, such as industrial production indexes, the public's indebtedness levels, retail sales, construction indexes, etc., which provide a very good indication of where the economy is heading. In this sense, it is not too far fetched to assume the policymaker knows the current level of economic activity.

As the data set consists of monthly observations, first a VAR system with twelve lags of each variable, a constant and a deterministic trend was estimated. ${ }^{2}$ The system is stable as all inverse roots of the autoregressive polynomials are inside the unit circle. The dynamic responses of real economic activity and prices to an unanticipated increase in the nominal interest rate are shown in Figure 1. The solid lines indicate the point estimates of the dynamic response functions, while dashed lines represent a $95 \%$ confidence interval.

2 As the ADF and PP tests for Output indicated that this variable may be considered $\mathrm{I}(0)$ when a deterministic trend is controlled for, the system was also estimated using Output in level. No different results were obtained regarding the impulse response functions or the model's adjustment. These results are not reported, but available upon request. 


\section{FIGURE 1 - RESPONSES OF OUTPUT, INFLATION AND THE EXCHANGE RATE TO A MONETARY SHOCK}

Response to Cholesky One S.D. Innovations \pm 2 S.E.
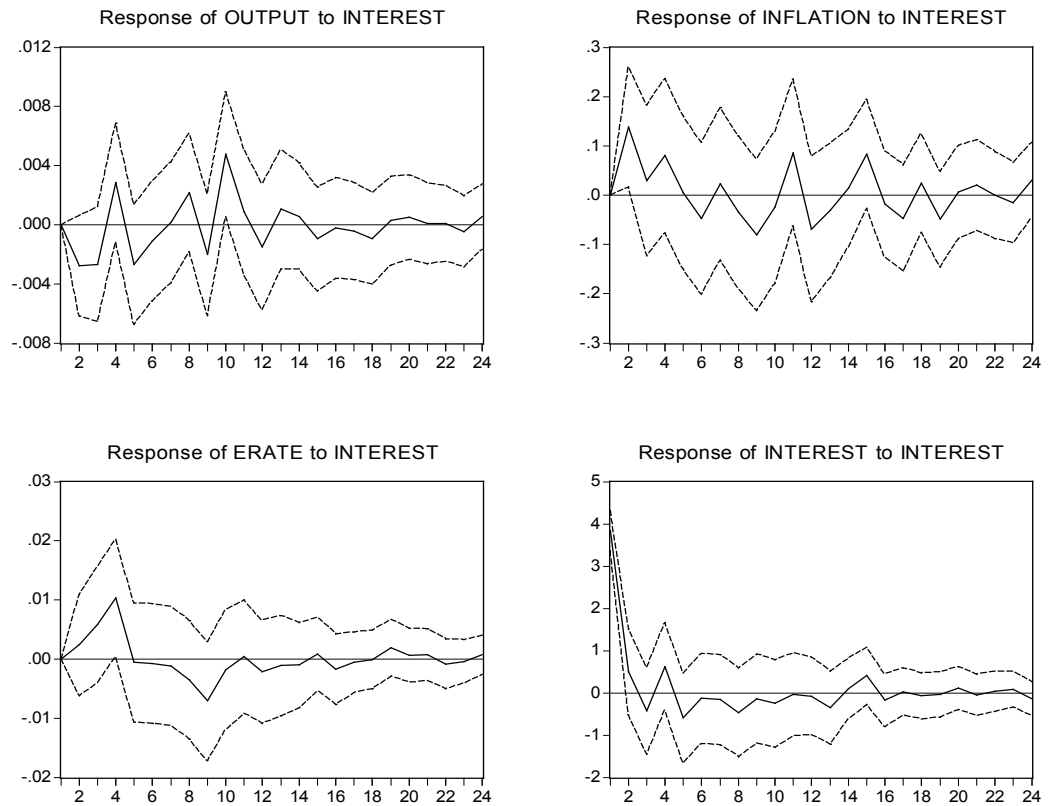

As one may see in the first graph, a tightening in the monetary policy has an immediate effect on economic activity, with the growth rate of real GDP reaching its lowest level in the second month following the shock. Real output tends to return to trend 12 months after the shock.

Inflation and the exchange rate actually rise immediately after the monetary shock, assuming a downward pattern thereafter. The pattern of the exchange rate indicates an initial depreciation of the domestic currency, relative to trend, following an unexpected tightening in the monetary policy. Real appreciation seems to occur only after the sixth month of the shock. These effects (on inflation and the exchange rate) are not supported by monetary theory but have commonly been reported in the empirical literature on the transmission mechanism using VAR (Eichenbaum, 1992). Known as the "price puzzle", these effects usually result from failure to include variables in the information set of the model that are in fact used by the policymaker. We will return to this discussion in the next section. 
The regression residual tests were tested for autocorrelation, heteroscedasticity and normality (see Table 2). The results indicate absence of autocorrelation or heteroscedastic autoregressive terms (ARCH), but indicate problems with normality. ${ }^{3}$

\section{TABLE 2 - AUTOCORRELATION, ARCH TERMS AND NORMALITY TESTS OF THE RESIDUALS}

\begin{tabular}{crllrllll}
\hline Lags & LM-Stat & Prob. & Dependent & Chi-q(98) & Prob. & Variables & Jarque-era & Prob. \\
\hline & & & & & & & & \\
1 & 20.867 & 0.184 & res1*res1 & 90.915 & 0.681 & Output & 12.472 & 0.002 \\
2 & 23.276 & 0.107 & res2*res2 & 108.347 & 0.223 & Inflation & 388.612 & 0.000 \\
3 & 15.988 & 0.454 & res3*res3 & 84.265 & 0.837 & Erate & 101.728 & 0.000 \\
4 & 20.165 & 0.213 & res4*res4 & 98.341 & 0.471 & Interest & 427.720 & 0.000 \\
5 & 21.569 & 0.158 & res2*res1 & 96.259 & 0.531 & & & \\
6 & 25.338 & 0.064 & res3*res1 & 99.396 & 0.442 & & & \\
7 & 12.362 & 0.719 & res3*res2 & 85.089 & 0.821 & & & \\
8 & 23.864 & 0.093 & res4*res1 & 97.177 & 0.505 & & & \\
9 & 6.822 & 0.977 & res4*res2 & 94.587 & 0.579 & & & \\
10 & 10.194 & 0.856 & res4*res3 & 97.371 & 0.499 & & & \\
11 & 19.896 & 0.225 & & & & & & \\
12 & 8.843 & 0.920 & & & & & & \\
13 & 11.385 & 0.785 & JointTest: & 936.934 & 0.835 & Joint Test & 930.532 & 0.000 \\
\hline
\end{tabular}

Note: High probability values indicate acceptance of the null of no autocorrelation, no heteroscedasticity and normality.

Information criteria were used to select a more appropriate specification for the number of lags to be included in the endogenous variables in the VAR. The Akaike information criterion suggests a model with 2 lags, the more stringent Schwarz criterion suggests only 1 lag and a sequential likelihood ratio test selected 8 lags. The VAR system was re-estimated with the number of lags suggested.

Estimation with 1 or 2 lags resulted in models whose residuals were strongly autocorrelated, heteroscedastic and non-gaussian, although the impulse response functions did not change in any substantial way.

The VAR system with 8 lags delivered a more parsimonious model, with well behaved residuals in terms of autocorrelation and heteroscedasticity, although not in normality (see Table 3). The impulse functions are shown in Figure 2.

3 Minella (2001)'s results also present problems with normality. 
FIGURE 2 - RESPONSES OF OUTPUT, INFLATION AND THE EXCHANGE RATE TO A MONETARY SHOCK, LAG LENGTH BASED ON INFORMATION CRITERIA

Response to Cholesky One S.D. Innovations \pm 2 S.E.
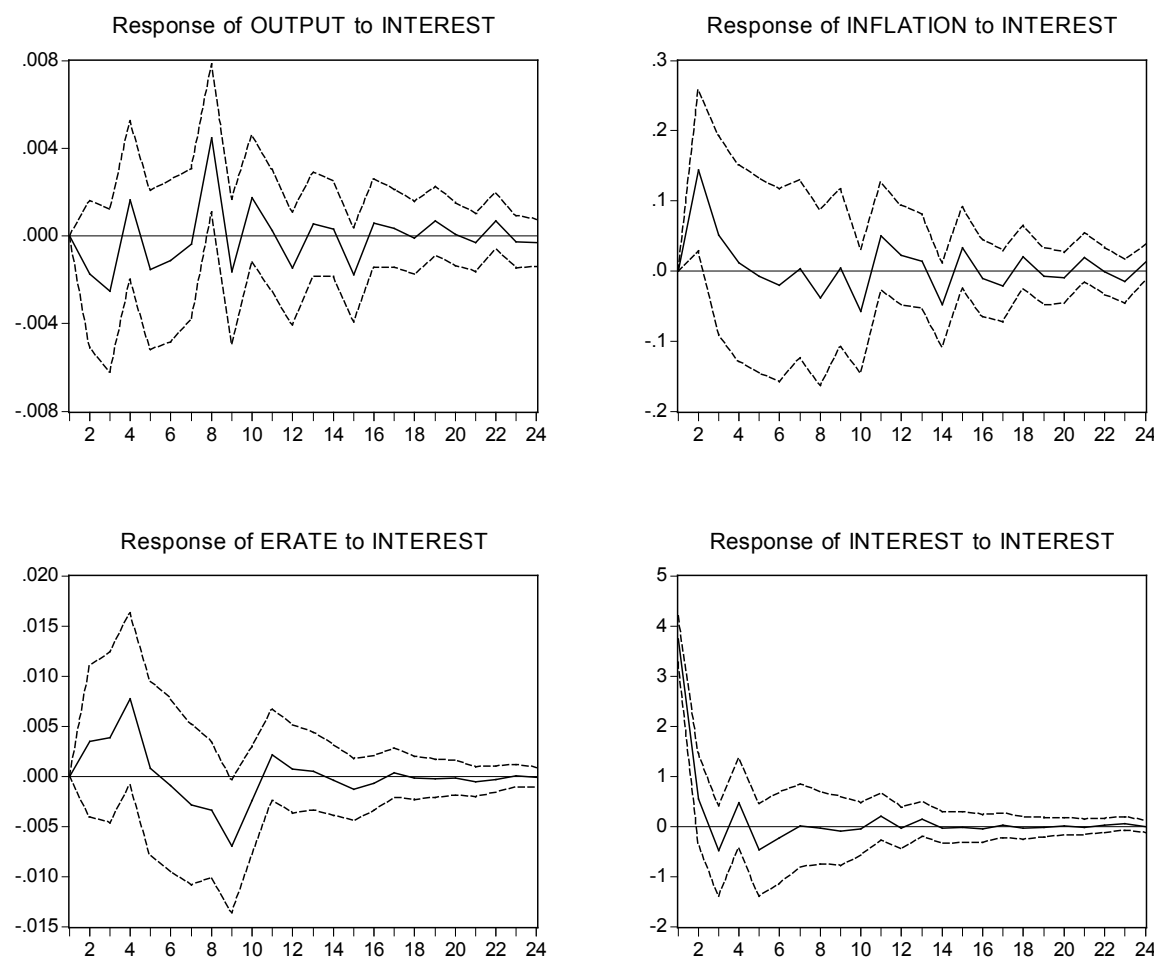

As one may see, the qualitative results presented in the impulse response functions of the first specification do not change: an unexpected shock to the interest rate immediately reduces the rate of growth of output, increases the growth rates of inflation and the exchange rate. Output returns to trend after a year, inflation begins a descent in the second period following the shock and the exchange rate depreciates after the sixth month. The results for output and inflation are in accordance to those presented by Minella (2001). 
TABLE 3 - AUTOCORRELATION, ARCH TERMS AND NORMALITY TESTS OF THE RESIDUALS

\begin{tabular}{|c|c|c|c|c|c|c|c|c|}
\hline Lags & LM-Stat & Prob. & Dependent & Chi-q(98) & Prob. & Variables & Jarque-Bera & Prob. \\
\hline 1 & 16.373 & 0.427 & res $1^{*}$ res1 & 72.273 & 0.279 & Output & 6.906388 & 0.032 \\
\hline 2 & 15.010 & 0.524 & res2*res2 & 70.283 & 0.336 & Inflation & 1411.336 & 0.000 \\
\hline 3 & 17.675 & 0.343 & res3*res3 & 50.663 & 0.919 & Erate & 383.0677 & 0.000 \\
\hline 4 & 21.767 & 0.151 & res4*res4 & 52.338 & 0.890 & Interest & 1235.573 & 0.000 \\
\hline 5 & 13.618 & 0.627 & res2*res1 & 68.187 & 0.403 & & & \\
\hline 6 & 24.916 & 0.071 & res3*res1 & 74.257 & 0.227 & & & \\
\hline 7 & 18.354 & 0.304 & res3*res2 & 48.809 & 0.944 & & & \\
\hline 8 & 9.294 & 0.901 & res4*res1 & 76.984 & 0.167 & & & \\
\hline 9 & 19.775 & 0.231 & res4*res2 & 48.424 & 0.949 & & & \\
\hline 10 & 17.542 & 0.351 & res4*res3 & 53.197 & 0.872 & & & \\
\hline 11 & 15.056 & 0.521 & & & & & & \\
\hline 12 & 9.605 & 0.886 & & & & & & \\
\hline 13 & 6.408 & 0.983 & Joint est: & 697.0192 & 0.1542 & Joint Test & 3036.883 & 0.000 \\
\hline
\end{tabular}

Note: High probability values indicate acceptance of the null of no autocorrelation, no heteroscedasticity and normality.

\section{ROBUSTNESS ANALYSIS AND THE "PRICE PUZZLE”}

This section presents a robustness analysis for the results obtained with the benchmark model by checking whether the qualitative results are sensitive to the period analyzed or to changing conditions in the international market. We also check whether the qualitative results change when variables as excluded or included in the information set in an attempt to solve the "puzzles" presented by the benchmark model.

\subsection{Sample Period and Exclusion of the Exchange Rate}

As the government launched a price stabilization program in 1994, it seems logical to analyze the sample sensitivity by dividing the period before and after July 1994. The VAR system was then re-estimated using 8 lags of each variable for one sub sample (1994:07 - 2001:08), period after the stabilization program. Although there were no qualitative changes in the results, we do not have enough degrees of freedom to estimate the system prior to 1994 and compare results. Moreover, due to the relatively small sample size, the estimated system using the sub sample got very imprecise, further impairing the sensitivity analysis. Instead, in order to use all the sample information and control for the price stabilization program of 1994 and the adoption of the floating exchange rate regime in 1999, the original system was re-estimated 
using two impulse dummies, $\mathrm{Dl}=1$ in 1994:07, 0 otherwise and $\mathrm{D} 2=1$ in 1999:01, 0 otherwise. The results are presented in Figure 4. Although the dummies are significant for some series, as one may observe, the pattern of the impulse response functions does not changed substantially ${ }^{4}$.

\section{FIGURE 4 - RESPONSES OF OUTPUT, INFLATION AND THE EXCHANGE RATE TO A MONETARY SHOCK, CONTROLLING FOR PRICE STABILIZATION AND FLOATING EXCHANGE REGIME}

Response to Cholesky One S.D. Innovations \pm 2 S.E.
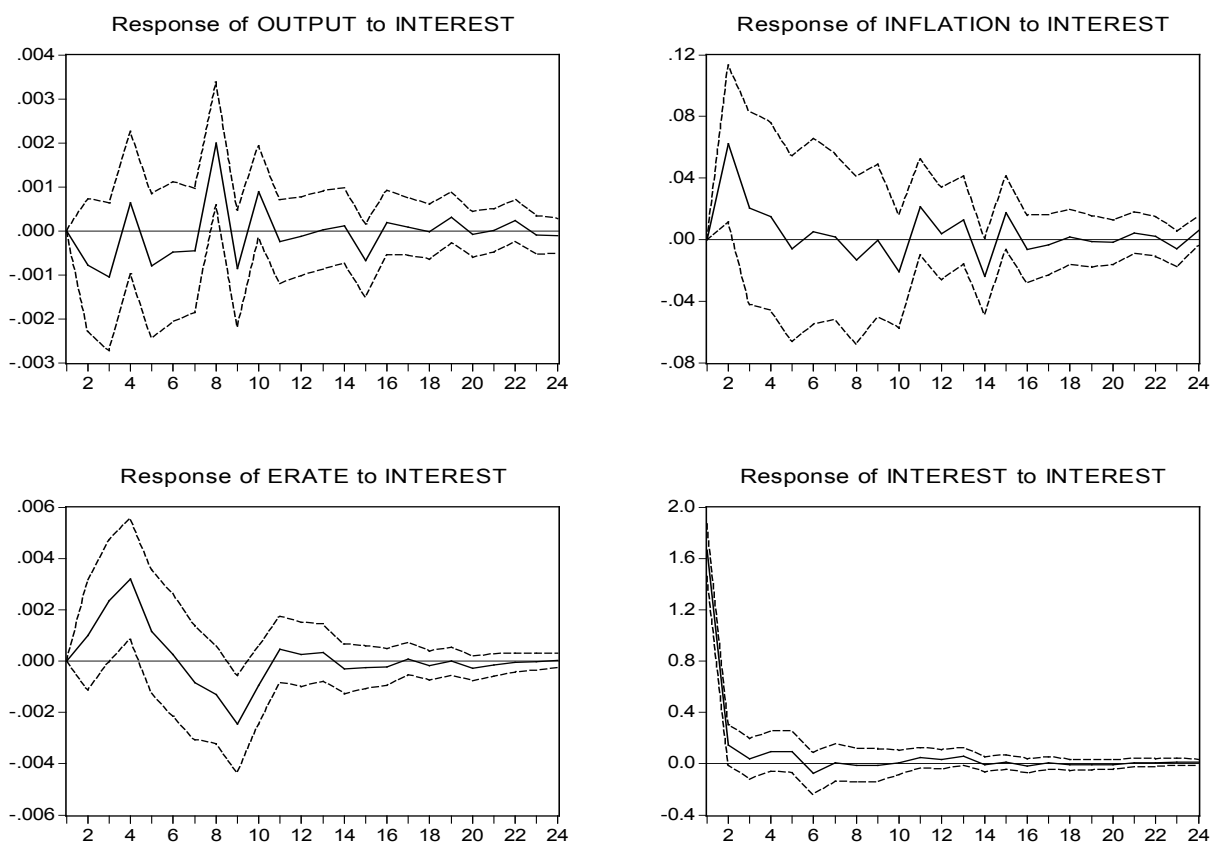

The robustness of the estimation can also be checked by eliminating some variables of the system and verifying whether the impulse response change substantially. During the sample period used for the analysis, the exchange rate regime has been changed. The price stabilization program of 1994 was based on a fixed exchange rate to the U.S. dollar. In January 1999, under a speculative attack, the Brazilian government liberalized the exchange rate, adopting a floating regime. In order to access the robustness of the analysis conducted so far, it seems interesting to re-estimate the VAR excluding the exchange rate from the system, while maintaining the same identification assumptions. The results are shown in Figure 3.

4 Based on an analysis of the residuals from the VAR, the system was also estimated with several other dummy variables, but they were either not significant for the variables of interest or delivered a systems with less well-behaved residuals, particularly regarding autocorrelation. 
FIGURE 3 - SYSTEM EXCLUDING THE EXCHANGE RATE FROM THE INFORMATION SET

Response to Cholesky One S.D. Innovations \pm 2 S.E.
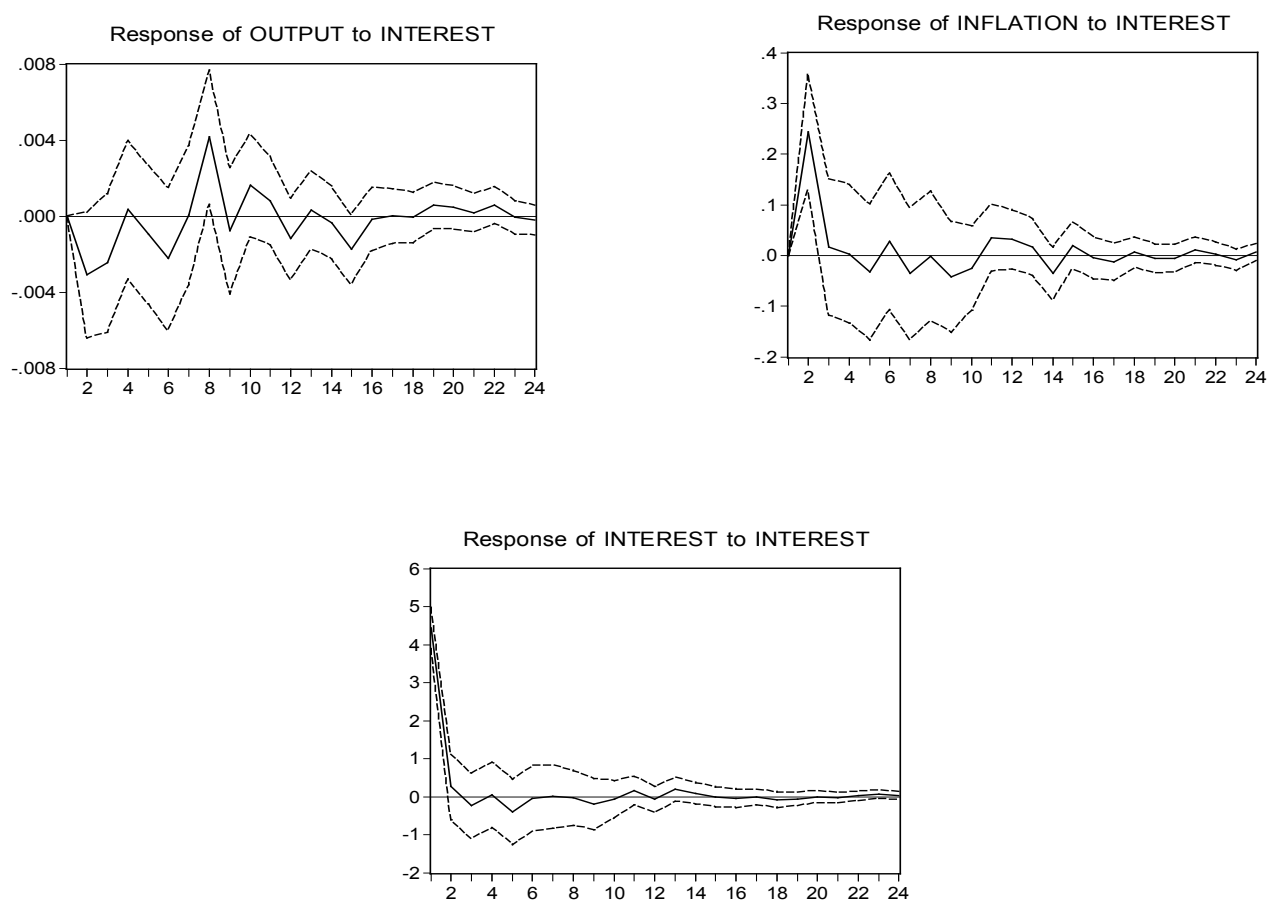

According to Figure 3, the response patterns of output and inflation to an unexpected policy shock are very similar to those portrayed in Figure 2. Output responds immediately to the shock and returns to its initial value 12 months later. As in Figure 2, here the inflation rate also rises after shock declining two periods after the shock.

\subsection{Controlling for International Conditions}

In order to take into account changing conditions in the international markets, an index for world exports and the U.S. Prime rate were included exogenously in the VAR system. The world exports' index is used as a proxy for international economic activity, which may have a positive correlation with domestic output; the U.S. Prime rate may in turn affect the exchange rate, influence the domestic monetary policy and the interest rate.

The coefficient of World Exports is significant for output, but not for inflation, exchange rate or interest rate; the coefficients for U.S. Prime rate are not statistically 
significant at conventional levels. As before, residuals are uncorrelated, homoscedastic, but not normal. The impulse response functions patterns remain very similar to the ones previously reported (see Figure 5), showing that the inclusion of the exogenous variables does not change the results in any significant way.

FIGURE 5 - RESPONSES OF OUTPUT, INFLATION AND THE EXCHANGE RATE TO A MONETARY SHOCK, CONTROLLING FOR INTERNATIONAL CONDITIONS

Response to Cholesky One S.D. Innovations \pm 2 S.E.
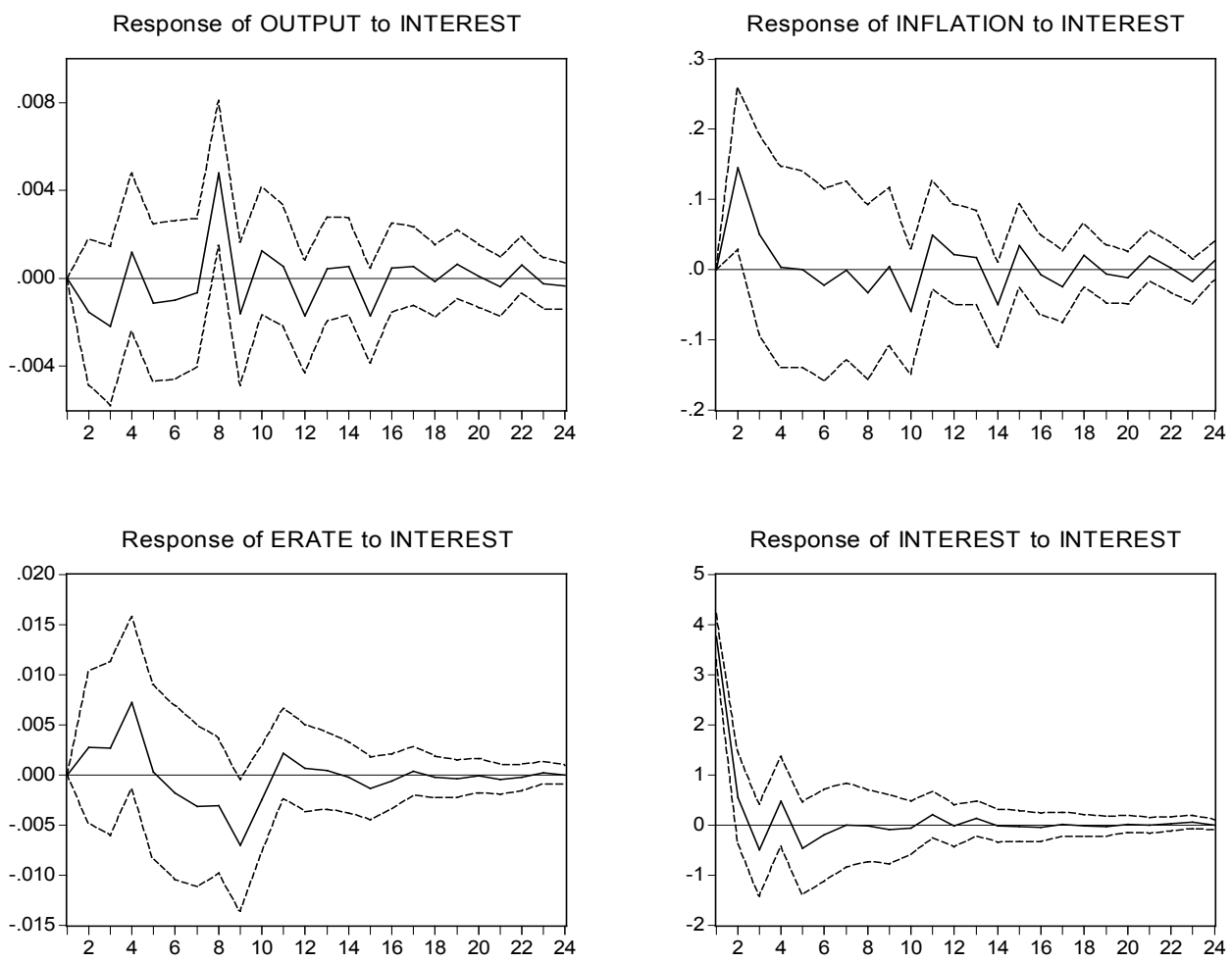

\subsection{The "Price Puzzle"}

As we have seen in previous sections, the standard specification of the information set used led to the implication that a tightening in the monetary policy results in a initial rise in domestic prices. This effect, although not supported by conventional theory of the monetary policy, has been commonly reported in the empirical literature on the monetary transmission mechanism using vector-autoregressions and became known as the "price puzzle" (Eichenbaum, 1992). According to Sims (1992), prices 
may appear to rise after a contractionary shock to the monetary policy because the analysis is based on a information set that does not include information on future inflation that is actually available to the authorities. For the American case, the inclusion of a commodity price index in the information set has often eliminated the "price puzzle" [Christiano et al (1996), Sims and Zha (1998)]. There, the inflation rate have been historically preceded by rises in commodity prices (Christiano et al, 1999). In addition, the evidence presented above show that besides the "puzzle" in prices, there is a "puzzle" in the exchange rate variable, a result that does not conform to theory or evidence (as shown by Eichenbaum and Evans,1995). The first question is then, does the inclusion of a commodity price index solve the "price puzzle" in the Brazilian case as it did for the American case? What about the "puzzle" in the exchange rate variable?

Data on commodity prices were collected from the International Financial Statistics Data Base, log transformed and tested for stationarity. As the unit root results (reported in Table 1) indicated the series to be first ordered integrated, the variable entered in the analysis in first difference.

The VAR system was re-estimated with 8 lags of Output, Inflation, Erate, Commodity and Interest, in this order, a constant and a deterministic time trend ${ }^{5}$. The impulse-response functions are reported in Figure 6.

As one may see from the second graph presented, the inclusion of a commodity price index does not solve the "price puzzle" or the "exchange rate puzzle" for Brazil. In fact, the responses to an unexpected change in the selic interest rate continues to be very similar to the ones previously reported. ${ }^{6}$

5 First a 12 lag VAR system was estimated, resulting in very similar response-functions.

6 Alternatively, the model was estimated controlling for oil prices exogenously and in the information set, with no changes in the results. 
FIGURE 6 - RESPONSE BY OUTPUT, INFLATION AND THE EXCHANGE RATE TO A MONETARY SHOCK, COMMODITY PRICES IN THE INFOR MATION SET

Response to Cholesky One S.D. Innovations \pm 2 S.E.
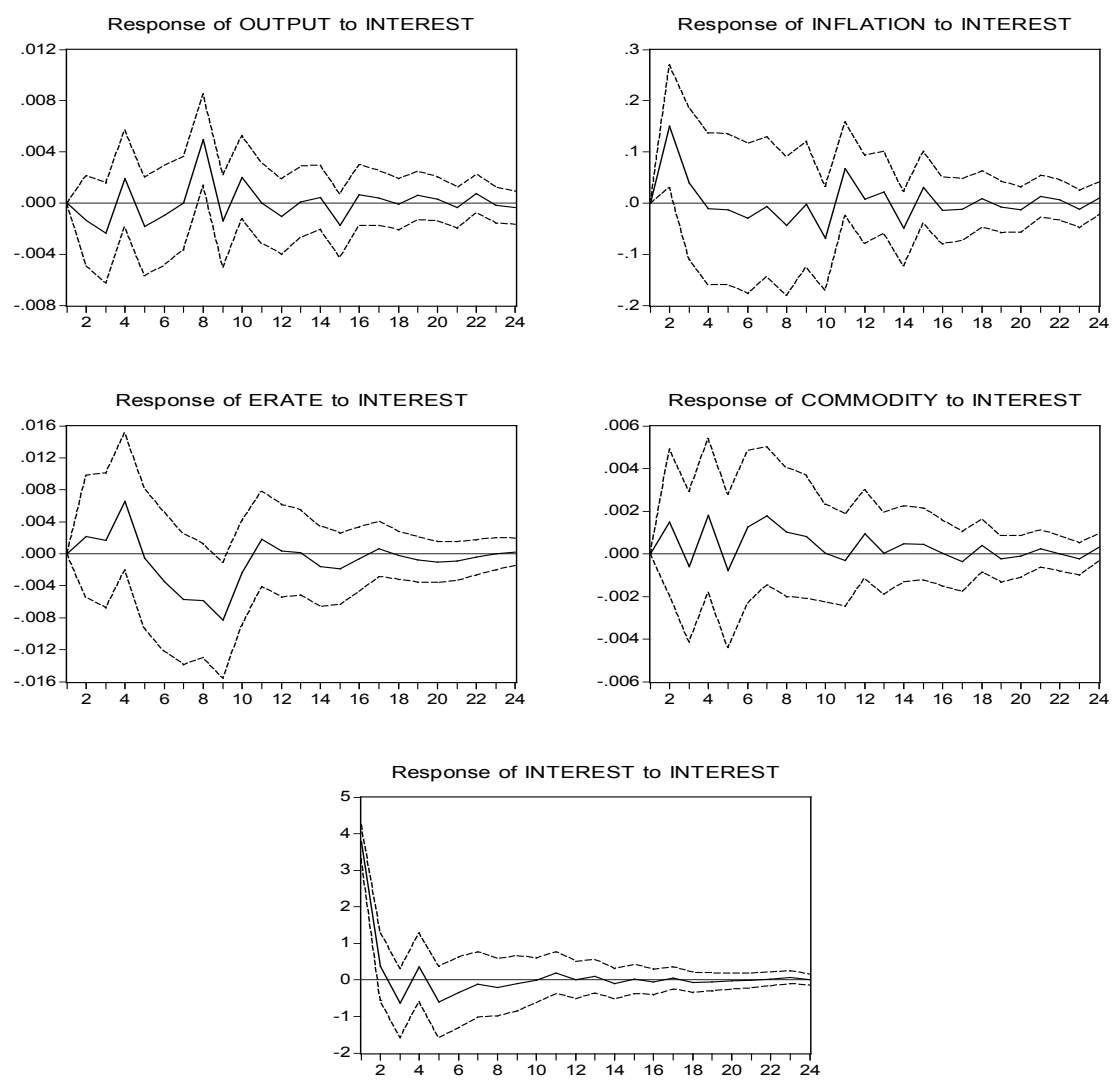

In the benchmark model, inflation was measured as a percentage change in the General Price Index, which is an average of wholesale prices, consumer price, and construction costs. Output consisted of monthly observations of GDP, seasonally adjusted at constant prices of 1990. This series, published by the Instituto Brasileiro de Geografia e Estatística (IBGE), has been discontinued after 2001, an indication that there might measurement errors in this variable. The benchmark model was then also estimated with a consumer price index (IPCA) and with a proxy for output, an industrial production index (quantum) ${ }^{7}$. The impulse response functions, reported in Figure 7 and Figure 8, have very similar patterns as the ones obtained by the benchmark model.

7 For comparability between the models, the variable IPCA_Index received the same treatment as Inflation, that is, the inflation rate measured as percentage change in the IPCA and log-transformed. As with the IGP- measured inflation rate, a constant $c=1.1$ was added to the whole sample in order to apply the log operator. 
FIGURE 7 - RESPONSE BY OUTPUT, INFLATION (IPCA) AND THE EXCHANGE RATE TO A MONETAR SHOCK

Response to Cholesky One S.D. Innovations \pm 2 S.E.

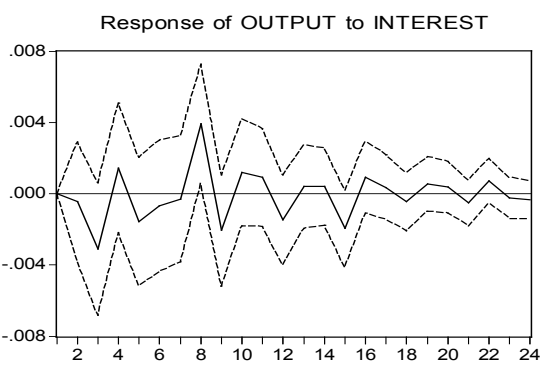

Response of IPCA_INDEX to INTEREST
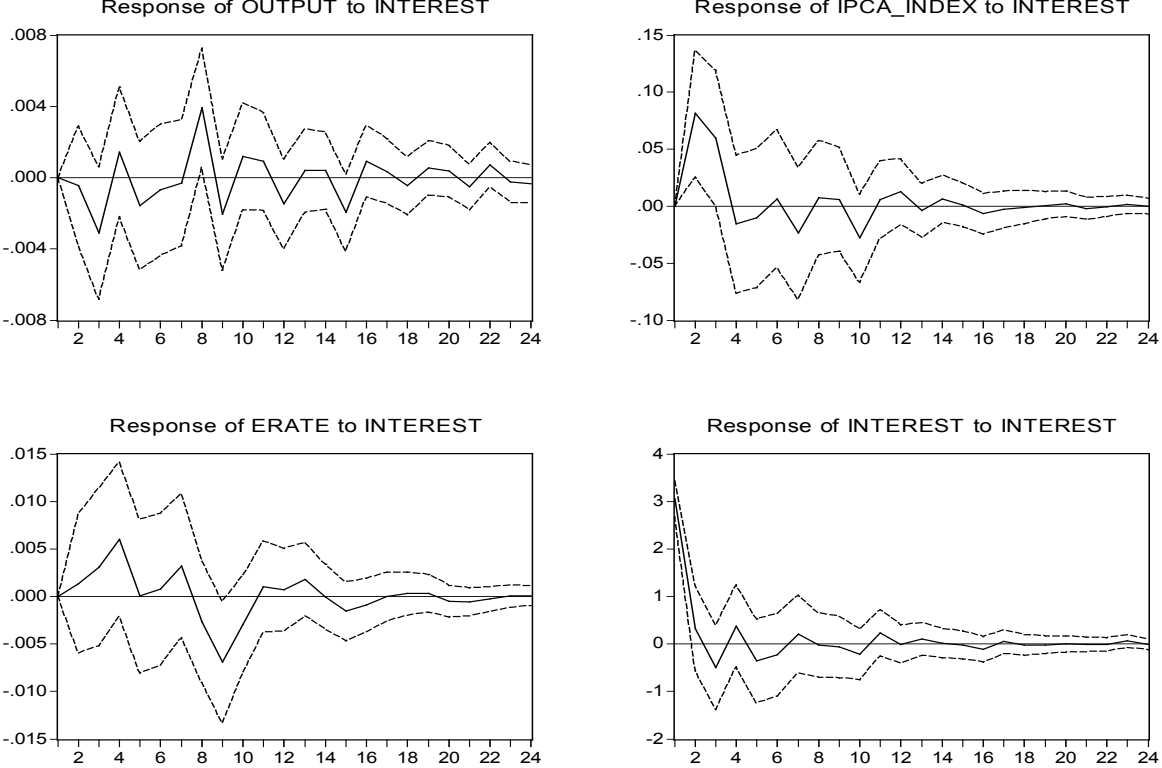

FIGURE 8 - RESPONSE BY PRODUCTION, INFLATION AND THE EXCHANGE RATE TO A MONETARY SHOCK

Response to Cholesky One S.D. Innovations \pm 2 S.E.
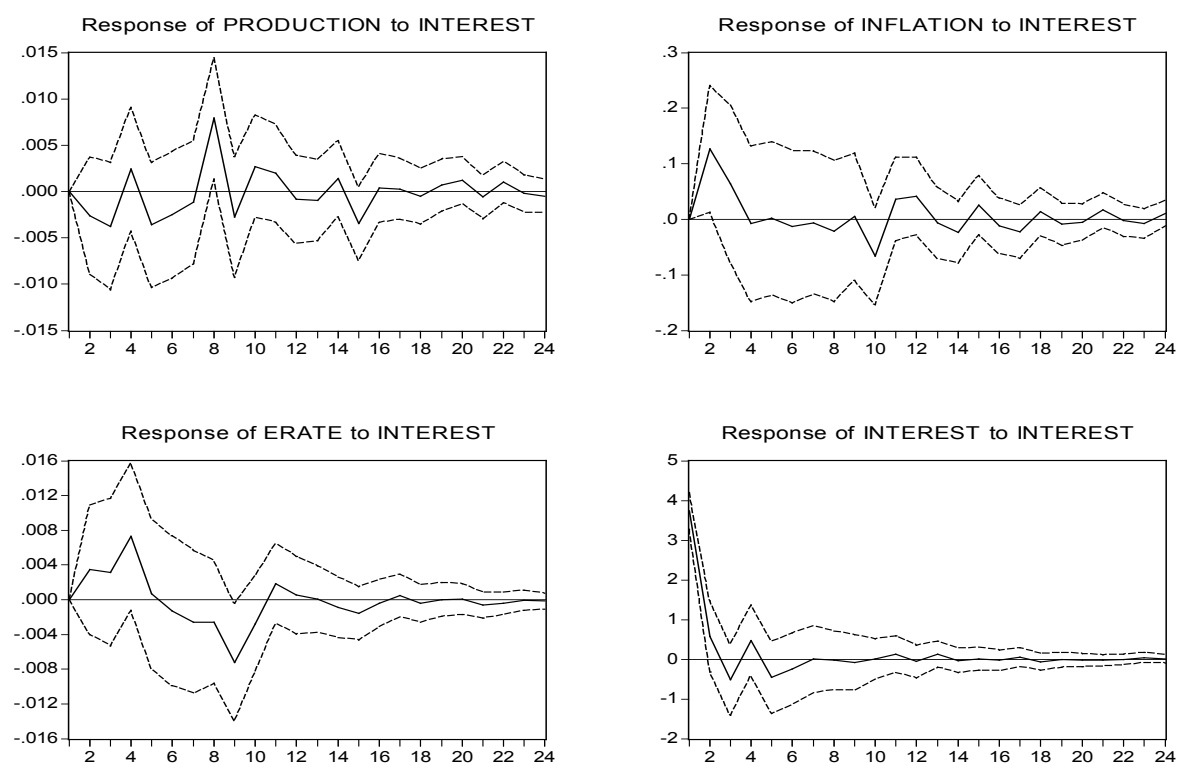
In Sargent and Wallace's unpleasant monetarist arithmetic (Sargent and Wallace, 1981), fiscal variables may affect prices in an institutional setting where the monetary authority does not act independently from the fiscal authority and set its monetary targets in accordance to the fiscal budget. Given the relatively recent and reportedly low independence of the Brazilian central bank and the attention international investors give to the fiscal stance of the government, a fiscal variable was included in the information set. ${ }^{8}$ Indeed, as Figure 9 indicates, the inclusion of the debt/GDP ratio in the government's information set solves the "puzzle" for the exchange rate that, as expected, appreciates after a contractionary shock to the domestic interest rate. The "price puzzle" remains however, with Inflation declining only after the second period. Debt increases immediately after the interest shock Given the relatively high participation of interest-indexed government securities and their short maturities, a shock to the selic rate has an immediate effect on the stock of government debt.

\section{FIGURE 9 - RESPONSE BY OUTPUT, INFLATION AND THE EXCHANGE RATE TO A MONETARY SHOCK, DEBT IN THE INFOR MATION SET}

Response to Cholesky One S.D. Innovations \pm 2 S.E.
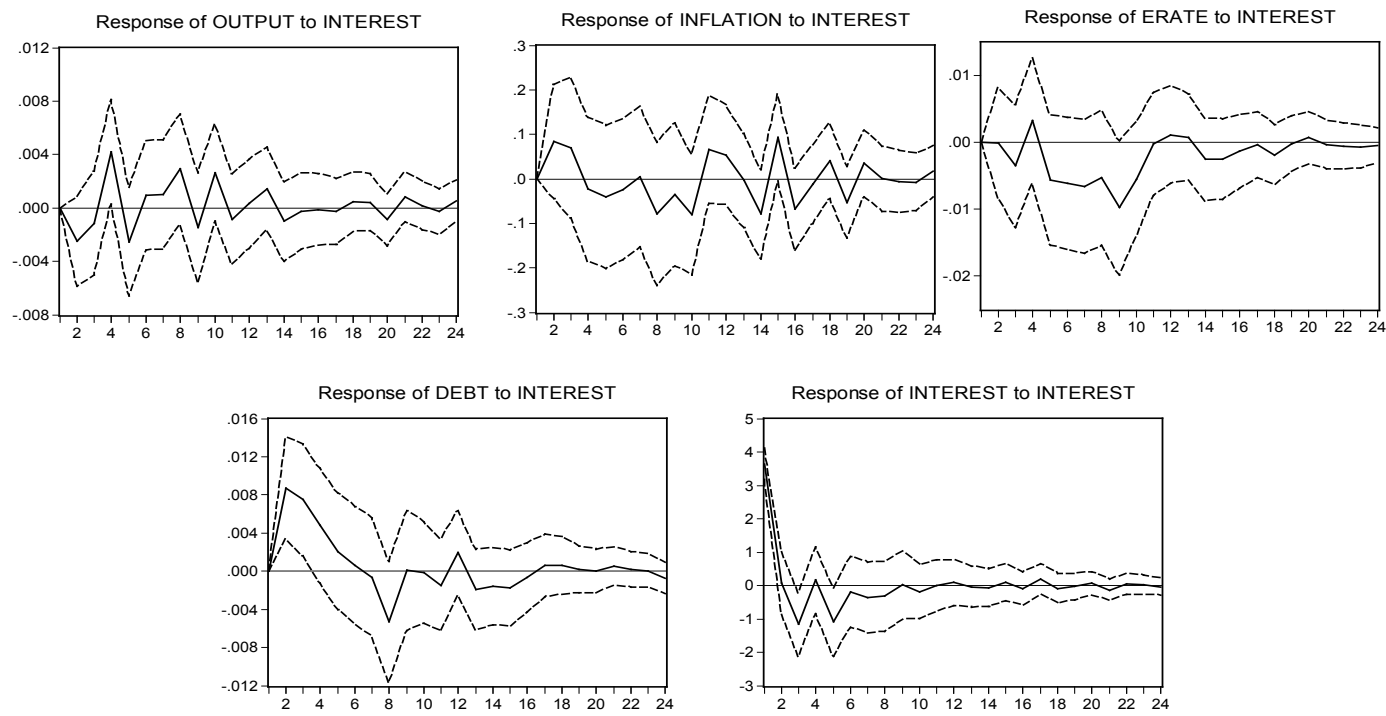

8 We thank an anonymous referee for making this suggestion. 


\section{VOLATILITY ANALYSIS}

In this section, we analyze how the monetary shocks have contributed to the volatility of the economic variables included in the information set of the estimated model (Christiano et al., 1999). Tables 4 and 5 show the percentage of the variance of the kperiod ahead forecast error in the variables of the benchmark model (Output, Inflation, Erate, Interest) and the control model (Output, Inflation, Erate, Debt, Interest).

In the benchmark model, the interest shock is relatively important for the volatility of the growth rate of output, significantly accounting for $8.0 \%, 9.1 \%$ and $9.7 \%$ of the variance of the 8,12 and 24 period-ahead forecast error variance, respectively. For inflation and the exchange rate, the interest shock significantly accounts for $6.0 \%$ of the variance of the 18 month-ahead forecast error variance in inflation and $7.8 \%$ of the variance of the 12 month-ahead forecast error in the exchange rate. As expected given the ordered of the variables in the var system, the monetary policy shock has an important impact on the volatility of the interest rate, significantly accounting for more than $60 \%$ of the forecast error variance throughout the period analyzed.

TABLE 4 - PERCENT OF K-PERIOD AHEAD FORECAST ERROR VARIANCE DUE TO INTEREST SHOCK, BENCHMARK MODEL

\begin{tabular}{lrrrrrrr}
\hline & \multicolumn{1}{c}{4} & \multicolumn{1}{c}{8} & \multicolumn{1}{c}{12} & 18 & 24 & 36 \\
\hline Output & 0.9 & 3.3 & 8.0 & 9.1 & 9.5 & 9.7 & 9.7 \\
& $(0.577)$ & $(0.985)$ & $(1.862)$ & $(1.927)$ & $(1.932)$ & $(1.873)$ & $(1.784)$ \\
& & & & & & & \\
$\begin{array}{l}\text { Infla- } \\
\text { tion }\end{array}$ & 4.0 & 4.4 & 4.4 & 5.4 & 6.0 & 6.1 & 6.2 \\
& $(1.317)$ & $(1.407)$ & $(1.335)$ & $(1.517)$ & $(1.666)$ & $(1.606)$ & $(1.580)$ \\
& & & & & & & \\
Erate & 0.7 & 4.4 & 5.2 & 7.8 & 7.9 & 7.9 & 7.9 \\
& $(0.391)$ & $(1.053)$ & $(1.179)$ & $(1.638)$ & $(1.586)$ & $(1.545)$ & $(1.497)$ \\
Inter- & & & & & & & \\
est & 69.6 & 65.3 & 64.6 & 64.0 & 63.8 & 63.7 & 63.7 \\
& $(10.403)$ & $(10.031)$ & $(9.791)$ & $(10.044)$ & $(9.985)$ & $(9.777)$ & $(9.136)$ \\
\hline
\end{tabular}

Ordering: OUTPUT INFLATION ERATE INTEREST; $\mathrm{t}$-values calculated based on Monte Carlo estimated standard errors in parenthesis; Significance levels: $t=1.645$ (10\%), $t=1.96(5 \%), t=$ $2.326(1 \%)$.

In the control model where the fiscal variable debt/GDP ratio is included in the authorities information set, the monetary shock does not have a statistically significant impact on the forecast error variance of output or inflation, indicating a low influence 
on the volatility of these variables. ${ }^{9}$ On the other hand, the monetary shock has an important and statistically significant impact on the volatility of the exchange rate and the debt/GDP ratio. The shock accounts for $11.9 \%$ and $12.4 \%$ of the 12 and 24 period-ahead forecast error variance of the exchange rate, respectively. The shock has also an important and significant impact on the volatility of the debt/GDP ratio, accounting for $20.2 \%$ of the 24 -period ahead forecast error variance.

TABLE 5 - PERCENT OF K-PERIOD AHEAD FORECAST ERROR VARIANCE DUE TO INTEREST SHOCK, CONTROL MODEL

\begin{tabular}{|c|c|c|c|c|c|c|c|}
\hline & 2 & 4 & 8 & 12 & 18 & 24 & 36 \\
\hline Output & $\begin{array}{r}2.0 \\
(0.735)\end{array}$ & $\begin{array}{r}7.1 \\
(1.398)\end{array}$ & $\begin{array}{r}9.9 \\
(1.432)\end{array}$ & $\begin{array}{r}11.4 \\
(0.819)\end{array}$ & $\begin{array}{r}11.6 \\
(1.552)\end{array}$ & $\begin{array}{r}11.9 \\
(1.506)\end{array}$ & $\begin{array}{r}12.0 \\
(1.332)\end{array}$ \\
\hline Inflation & $\begin{array}{r}1.4 \\
(0.192)\end{array}$ & $\begin{array}{r}2.3 \\
(0.793)\end{array}$ & $\begin{array}{r}3.3 \\
(0.850)\end{array}$ & $\begin{array}{r}5.4 \\
(1.022)\end{array}$ & $\begin{array}{r}8.2 \\
(1.291)\end{array}$ & $\begin{array}{r}8.5 \\
(1.229)\end{array}$ & $\begin{array}{r}8.6 \\
(1.116)\end{array}$ \\
\hline Erate & $\begin{array}{r}0.0 \\
(0.000)\end{array}$ & $\begin{array}{r}1.1 \\
(0.373)\end{array}$ & $\begin{array}{r}7.2 \\
(0.573)\end{array}$ & $\begin{array}{r}11.9 \\
(1.882)\end{array}$ & $\begin{array}{r}12.4 \\
(1.795)\end{array}$ & $\begin{array}{r}12.4 \\
(1.628)\end{array}$ & $\begin{array}{r}12.5 \\
(1.408)\end{array}$ \\
\hline Debt & $\begin{array}{r}11.0 \\
(1.810)\end{array}$ & $\begin{array}{r}19.6 \\
(2.691)\end{array}$ & $\begin{array}{r}20.8 \\
(3.045)\end{array}$ & $\begin{array}{r}19.7 \\
(2.882)\end{array}$ & $\begin{array}{r}20.2 \\
(3.008)\end{array}$ & $\begin{array}{r}20.2 \\
(2.975)\end{array}$ & $\begin{array}{r}20.2 \\
(2.611)\end{array}$ \\
\hline Interest & $\begin{array}{r}73.8 \\
(11.589)\end{array}$ & $\begin{array}{r}66.7 \\
(9.608)\end{array}$ & $\begin{array}{r}65.3 \\
(9.526)\end{array}$ & $\begin{array}{r}64.5 \\
(9.228)\end{array}$ & $\begin{array}{r}64.0 \\
(8.606)\end{array}$ & $\begin{array}{r}63.9 \\
(8.023)\end{array}$ & $\begin{array}{r}63.8 \\
(7.334)\end{array}$ \\
\hline
\end{tabular}

Ordering: OUTPUT INFLATION ERATE DEBT INTEREST; t-values calculated based on Monte Carlo estimated standard errors in parenthesis; $t=1.645(10 \%), t=1.96(5 \%), t=2.326(1 \%)$.

In both models, the benchmark and the control model, the variation of the forecast errors due to the policy shock are limited however, indicating that interest rate shocks have not been the most important independent source of volatility for these macroeconomic variables.

\section{FINAL REMARKS}

This article has analyzed the transmission mechanism of the Brazilian monetary policy during the 1990s using a standard specification of the information set of the monetary authorities, where the current level of economic activity, the inflation rate and the exchange rate are taken into account when setting its policy variable, the baseline interest rate. The results have indicated that a tightening in the monetary

9 Christiano et al. (1999) also find that monetary shocks do not account much for the volatility of prices. 
policy immediately reduces economic activity, but only affects prices and the exchange rate with a temporal lag. The robustness analysis conducted supports these main results.

The standard specification of the information set used led to the implication that a tightening in the monetary policy results in a initial rise in domestic prices. This effect, not supported by conventional theory of the monetary policy, has been commonly reported in the empirical literature on the monetary transmission mechanism using vector-autoregressions and became known as the "price puzzle" (Eichenbaum, 1992). Moreover, the benchmark model indicates an "exchange rate puzzle", as a contractionary shock leads to a depreciation of the domestic currency relative to trend. These "puzzles" may reflect the choice of variables in the governments information set. For the American case, the inclusion of a commodity price index in the information set has often eliminated the "price puzzle". For Brazil, the results have indicated that the commodity price index or other variables, such as oil prices, have not solved the "price puzzle". The "puzzle" in the exchange rate variable is removed, however, when the debt/GDP ratio is endogenously included in the model, indicating that fiscal variables have an important role in the government's information set.

\section{REFERENCES}

Ball, L. Time-consistent policy and persistent changes in inflation. Journal of Monetary Economics, v.36, n.2, p. 329-350, 1995.

Barbosa, F. H.; Portugal, P. A. A transmissão da política monetária no Brasil: o canal da taxa de juros. Rio de Janeiro: FGV, 2002. (Mimeografado)

Barro, R. Unanticipated money growth and unemployment in the United States. American Economic Review, v. 67, n.2, p. 101-115, 1977.

Barth, M.; Ramey, V. The cost channel of monetary transmission. NBER Working Paper No. 7675, 2000.

Bernanke, B.; Blinder, A. The federal funds rate and the channels of monetary transmission. American Economic Review, v.82, n.3, p. 901-921, 1992.

Bernanke, B.; Gertler, M. Inside the black box: the credit channel of monetary policy transmission. Journal of Economic Perspective, v.9, n.4, p. 27-48, 1995.

Bernanke, B.; Mihov, I. Measuring monetary policy. NBER Working Paper 5145, 1995.

Blanchard, O. Why does money affect output? A survey. In: Friedman, B.; Hahn, F. (eds.). Handbook of Monetary Economics, v. 2. Amsterdam: North Holland, 1990. 
Chari, V.; Christiano, L.; Eichenbaum, M. Expectation traps and discretion. Journal of Economic Theory, v.81, n.2, p. 462-492, 1998.

Christiano, L.; Eichenbaum, M.; Evans, C. L. Identification and the effects of monetary policy shocks. Federal Reserve Bank of Chicago, Working Paper 94-7, 1994.

. The effects of monetary policy shocks: evidence from the flow of funds. Review of Economics and Statistics, v.78, n.1, p.16-34, 1996.

- Monetary policy shocks: what have we learned and to what end? In: Taylor, J.; Woodford, M. (eds.). Handbook of Macroeconomics, v. 1A. Amsterdam: North Holland, 1999.

Cochrane, J. H. Shocks. Carnegie-Rochester Conference Series on Public Policy 41, p.1-56, 1994.

. What do the VARs mean? Measuring the output effects of monetary policy. Journal of Monetary Economics, v. 41, n. 2, p. 277-300, 1998.

Cook, T.; Hahn, T. The effect of changes in the Federal Funds rate target on market interest rates in the 1970s. Journal of Monetary Economics, 24, p. 331-51, 1989.

Eichenbaum, M. Comment on interpreting the macroeconomic time series facts: the effects of monetary policy. European Economic Review, v. 36, n.5, p.1001$1011,1992$.

Eichenbaum, M.; Evans, C. Some empirical evidence on the effects of shocks to monetary policy on exchange rates. The Quarterly Journal of Economics, v.110, n. 4, p.975-1009, 1995.

Friedman, M.; Schwartz, A. A monetary history of the United States, 1867-1960. Princeton, NJ: Princeton University Press, 1963.

Hayashi, F. Econometrics. Princeton, NJ: Princeton University Press, 2000.

Mendonça, H. F. Mecanismos de transmissão monetária e a determinação da taxa de juros: uma aplicação da regra de Taylor ao caso brasileiro. Economia e Sociedade $16,2001$.

Minella, A. Monetary policy and inflation in Brazil. Working Paper Series 33, Banco Central do Brasil, 2001.

Peersman, G.; F. Smets, F. The monetary transmission mechanism in the Euro area: more evidence from VAR analysis. European Central Bank, Working Paper 91, 2001.

Reichenstein, W. The impact of money on short-term interest rates. Economic Inquiry, v. 25, n.11, p. 67-82, 1987.

Romer, C.; Romer, D. Does monetary policy matter? A new test in the spirit of Friedman and Schwartz. NBER Macroeconomics Annual 4, p. 121-170, 1989. 
Sargent, T.; Wallace, N. Some unpleasant monetarist arithmetic. In: Preston, M. The rational expectations revolution: readings from the front line, 1994. Cambridge: The MIT Press, 1981.

Sims, C. Interpreting the macroeconomic time series facts: the effects of monetary policy. European Economic Review, v. 36, n.5, p.975-1000, 1992.

Sims, C.; Zha, T. Does monetary policy generate recessions? Working Paper 98-12, Federal Reserve Bank of Atlanta, 1998.

\section{APPENDIX}

The raw data set was obtained from IPEA (site: www.ipea.gov.br).The following variables were downloaded:

Inflação: IGP:DI \%

Taxa de câmbio - R\$ / US\$ - comercial - venda - média - Mensal - R\$

IPC - índice (média $1995=100)$ - EUA - Mensal

IGP - índice (Dec95=100) - Brasil - Mensal

PIB - preços de mercado - índice encadeado (média $1990=100$ ) - Mensal

- Brasil

Taxa de juros - Over / Selic (\% a.m.) - Mensal

Exportações Mundiais- índice (média 1995=100)

Prime - taxa de juros EUA, mensal (IFS12)

IPCA - geral - índice (dez. $1993=100)$ - Mensal - IBGE/SNIPC

- Precos12_IPCA12

Produção industrial - indústria geral - quantum - índice (média $1991=100$ )

- Mensal - BRASIL

Debt - dívida interna - setor público - líquida- mensal- (\%PIB) - BCB

Boletim/F.Públ. - Bml2_DINSPY12

Data on commodity prices and oil prices were obtained from the Financial International Statistic Data Base:

Commodity Price Index, baseyear 1995, series code: 00176AXDZF.

Petroleum, spot average crude price, baseyear 1995, series code: 00176AADZF. 